\title{
Quality Assessment of Waste Waters Generated by some Important Hospitals from Cluj County
}

\author{
Ocsana OPRIŞ ${ }^{1}$, Carmen ROBA ${ }^{2 *}$, Florina COPACIU ${ }^{3}$, Andrea BUNEA ${ }^{3}$ \\ ${ }^{1}$ National Institute for Research and Development of Isotopic and Molecular Technologies, \\ 67-103 Donat, Cluj-Napoca 400293, Romania \\ ${ }^{2}$ Babeş-Bolyai University, Faculty of Environmental Science and Engineering, \\ 30 Fântânele, 400294 Cluj-Napoca, Romania \\ ${ }^{3}$ Faculty of Animal Science and Biotechnologies, University of Agricultural Sciences and Veterinary \\ Medicine, 3-5 Mănăștur, Cluj-Napoca 400372, Romania \\ *corresponding author, e-mail: carmen.roba@ubbcluj.ro
}

Bulletin UASVM series Agriculture 73(1)/2016

Print ISSN 1843-5246; Electronic ISSN 1843-5386

DOI 10.15835/buasvmcn-agr: 12016

\begin{abstract}
Hospitals produce large quantities of waste water that may contain various potentially hazardous materials. Moreover, these effluents usually do not undergo any specific treatment before being discharged into the urban sewage networks. As a consequence, a proper management of the hospitals effluents is vital. In the present study, the quality of the effluents, generated by 11 important hospitals from Cluj County was investigated. The analyzed parameters were: $\mathrm{pH}$, chemical and biochemical oxygen demand, total suspended solids, residual free chlorine, and detergents. For all the effluents, the biochemical oxygen demand and the detergents content were within the permissible limits for waste water discharged in the urban sewerage system, while the other parameters exceeded the permissible limits.
\end{abstract}

Keywords: hospital effluent, waste water, water quality, physicochemical parameter

\section{INTRODUCTION}

During the last decades, the production and the consumption of pharmaceuticals have increased rapidly due to the development of medical science. Approximately 3000 compounds are used as medicine, and the annual production amount exceeds hundreds of tons (Kümmerer, 2009; Sim et al., 2011). Hospitals use a variety of chemical substances such as pharmaceuticals, radionuclides, solvents and disinfectants for medical purposes as diagnostics, disinfections and research (Sim et al., 2011). They are the main source of pharmaceutical compounds $(\mathrm{PhCs})$ released into the environment. Hospitals are important water consumers too. Generally, the hospitals water demand varies from 400 to
1200 l/bed/day, with a minimal domestic water consumption of $100 \mathrm{l} /$ person/day (Emmanuel et al., 2005). In the developing countries the hospital average water consumption is estimated at $500 \mathrm{l} /$ bed/day, while in the developed countries this value can be double, for example in the USA reaches 968 l/bed/day (Emmanuel et al., 2005). As a consequence, hospitals generate significant volumes of waste water which end into the municipal sewerage network or surface water. Sometimes the hospital effluents are discharged without a preliminary treatment, releasing many toxic substances into the aquatic environment (Emmanuel et al., 2005). These waste waters can have potential negative effects on biological balance of natural environments, because of 
the exposure to hazardous substances like viruses, pathogenic bacteria disinfectants, nonmetabolized pharmaceuticals and radionuclides (Emmanuel et al., 2005). There are many studies (Emmmanuel et al., 2004; Emmanuel et al., 2005; Heberer, 2002) which have reported the toxic effects of hospital waste water on the aquatic organisms.

The objectives of the present study were to investigate the quality of several effluents generated by 11 important hospitals located in Cluj County. The analyzed parameters were $\mathrm{pH}$, chemical oxygen demand (COD), biochemical oxygen demand $\left(\mathrm{BOD}_{5}\right)$, total suspended solids (TSS), detergents and residual free chlorine content. The analyzed effluents are discharged into the urban sewerage system, finally ending into the surface waters. The levels of the analyzed physicochemical parameters were compared with the permissible limits set by the Romanian and UE legislation, for waste water discharge into the urban sewerage systems. The Council Directive 91/271/EEC concerning the urban waste water treatment was fully transposed into the Romanian legislation through the Governmental Decision no. 188/2002 (revised by the Governmental Decision no. 352/2005), regarding the approval of certain norms concerning the conditions of waste water discharge into the aquatic environment. The Annex no.3 (NTPA 001/2005) contains the "Normative establishing the pollutants limits for urban and industrial waste water discharged into natural receivers", while the Annex no.2 (NTPA 002/2005) contains the "Normative establishing the pollutants limits for urban and industrial waste water discharged into the local sewerage networks and waste water treatment plants".

\section{MATERIALS AND METHODS}

In the present study, 11 important hospitals were investigated. These hospitals are located in Cluj County, north-western Romania, a county with a total surface of $6674 \mathrm{~km}^{2}$ and 680000 of inhabitants. 9 of the hospitals are located in Cluj-Napoca, one in Dej and another in Huedin (Fig. 1). The selected hospitals have a wide spectrum of wards and services. The general characteristics of the investigated hospitals are summarized in Table 1. The main classes of drugs used in these hospitals are: antibiotics (oxacillin, penicillin G, amoxicillin, ampicillin, ceftazidime, ceftriaxone, cefuroxime, ciprofloxacin, ofloxacin, cefaclor, tetracycline, doxycycline, azithromycin); analgesics and anti-inflammatories (oxycodone, dihydrocodeine, tramadol, lansoprazole, tenoxicam, diclofenac, ketoprofen, ibuprofen); cytostatics (busulfan); anaesthetics (thiopental, inactin, propofol, ketamine); antihypertensives (irbesartan, indapamide); disinfectants (triclosan, glutaraldehyde); psychiatric drugs (alprazolam, zolpidem, carbamazepine, haloperidole, aripiprazole); antidiabetics (exenatide) and hormones (estradiol, estriol, estrone).

The samples were collected at their discharge point. The waters were sampled in plastic containers that were previously cleaned by washing in non-ionic detergent, rinsed with tap water and later soaked in $10 \% \mathrm{HNO}_{3}$ for 24 hours and finally rinsed with deionised water prior to usage. During sampling, the sample bottles were rinsed with sampled water three times and then they were filled to the brim. The samples were labelled and transported to the laboratory, stored in the refrigerator at $4^{\circ} \mathrm{C}$, at dark and analyzed within 24 hours from sampling. The effluent samples were collected during 2008 and 2011. The samples were analyzed for various physicochemical parameters using specific standard procedures: pH (SR ISO 10523:2009), COD (SR ISO 6060:1996), BOD (SR ISO 1899/1:2008), TSS (SR EN 872:2009), detergents (SR EN 903:2003), and residual free chlorine (SR EN 7393/2:2002). The $\mathrm{pH}$ was measured in the field, while the other parameters were analyzed in the laboratory within 24 hours from the sampling. The field meters and the equipment were checked and calibrated according to the manufacturer's specifications.

\section{RESULTS AND DISCUSSION}

$p H$

The water $\mathrm{pH}$ influences most of the chemical and biochemical reactions. As a consequence, the $\mathrm{pH}$ values of the studied effluents affect the physicochemical properties of the water and have an important impact on the aquatic life.

The $\mathrm{pH}$ values of the effluents varied significantly (6.2 - 10.2), being in general slightly alkaline. As it is shown in Fig. 2, the highest $\mathrm{pH}$ levels were determined in the effluents collected from the Cluj-Napoca hospitals (6.3 - 10.2, with a mean value of 7.8). The $\mathrm{pH}$ values were lower in 
Dej (6.6 - 8.4, with an average value of 7.2) and Huedin (6.7 - 7.65, with an average value of 7.2).

The $\mathrm{pH}$ values of the effluents generated by several hospitals from Cluj-Napoca exceeded the $\mathrm{pH}$ permissible limit (6.5 - 8.5) for waste water discharge in the urban sewerage system. Occasionally, the effluents generated by C_2, C_4 and $C_{-} 7$ were too basic (for $C_{-} 4$ levels up to 10.2), while other times $C_{-} 4$ effluents were too acidic than the limit values. These fluctuations demonstrate the types and amount of some drugs which were administrated in the hospitals shortly before the sampling time. The data results demonstrate that the $\mathrm{pH}$ fluctuation is slightly dependent by seasons (Fig. $3 \mathrm{~A}$ ). The $\mathrm{pH}$ values were higher in the summer and autumn than in winter.

The effluents collected from Dej and Huedin hospitals had the $\mathrm{pH}$ values within the allowed limits. This can be due to the low hospital dynamics; the hospitals are located in small urban agglomerations and rarely are functioning at their maximum capacity. The high $\mathrm{pH}$ levels registered

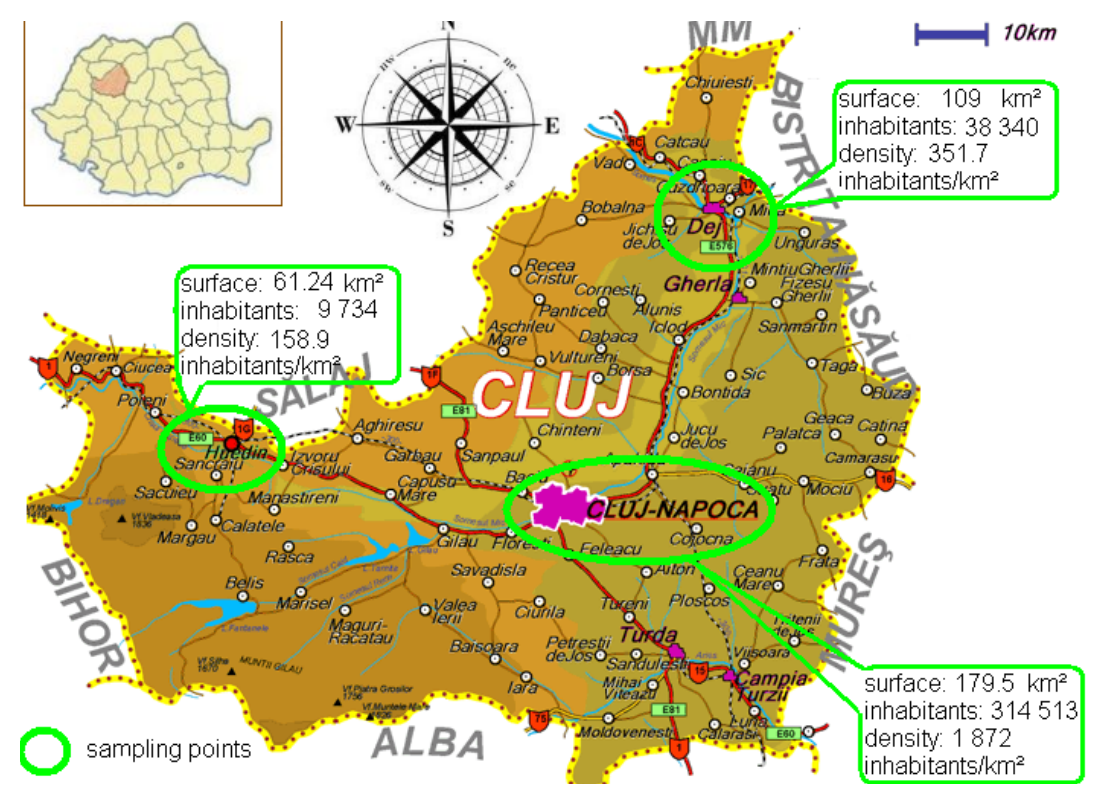

Fig. 1. Location of the sampling points

Tab. 1. General characteristics of the investigated hospitals

\begin{tabular}{|c|c|c|c|c|}
\hline Hospital code & Location & Type & No. of beds & Main classes of compounds \\
\hline C_1 & Cluj-Napoca & Oncologic & 310 & \multirow{11}{*}{$\begin{array}{c}\text { Antibiotics } \\
\text { Analgesics and anti- } \\
\text { inflammatories } \\
\text { Cytostatics } \\
\text { Anaesthetics } \\
\text { Antihypertensives } \\
\text { Disinfectants } \\
\text { Psychiatric drugs } \\
\text { Antidiabetics } \\
\text { Hormones }\end{array}$} \\
\hline C_2 & Cluj-Napoca & Clinic & about 60 & \\
\hline C_3 & Cluj-Napoca & Paediatric & $\begin{array}{c}90 \text { (C_3_I) } \\
80 \text { (C_3_II) } \\
30 \text { (C_3_III) } \\
44 \text { (C_3_VI) }\end{array}$ & \\
\hline C_4 & Cluj-Napoca & Clinic & 237 & \\
\hline C_5 & Cluj-Napoca & Pneumology & 230 & \\
\hline C_6 & Cluj-Napoca & Dialysis & $<50$ & \\
\hline C_7 & Cluj-Napoca & Clinic & $<50$ & \\
\hline C_8 & Cluj-Napoca & Gynaecologic & 12 & \\
\hline C_9 & Cluj-Napoca & Urologic & $<50$ & \\
\hline $\mathrm{H}$ & Huedin & Clinic & 137 & \\
\hline $\mathrm{D}$ & Dej & Clinic & 373 & \\
\hline
\end{tabular}


in the $C_{-} 2, C_{-} 4$ and $C_{-} 7$ effluents represent a risk for the aquatic life, because a $\mathrm{pH}$ over 8.5 can have a negative impact on the aquatic organisms. For example, it affects the dissolved oxygen level, slowing down the aquatic plants photosynthesis, or it inhibits the growth of the aquatic macrophytes by impairing iron and phosphorus uptake, and it reduces the fish production (Kumar et al., 2010). Such high $\mathrm{pH}$ levels can also damage the waste water collection and treatment facilities (reducing germicidal potential of chloride) and prevent the biological treatment processes (Kumar et al., 2010; WHO, 1996). High $\mathrm{pH}$ can also induce the formation of toxic substances like trihalomethanes.

Chemical oxygen demand (COD) and biochemical oxygen demand $\left(B O D_{5}\right)$

The COD and $\mathrm{BOD}_{5}$ parameters are used in order to characterize the amount of the organic matter from the waste water. COD shows the pollutant loading from the water through the presence of the organic and inorganic matters. The organic and inorganic matters are chemical oxidized by strong agents such as potassium dichromate and concentrated sulphuric acid. BOD $_{5}$ is an indicator of the oxygen-request properties of the biodegradable material from the water. High COD levels can demonstrate the toxic condition and reflect the presence of the resistant organic substances from biological point of view. The

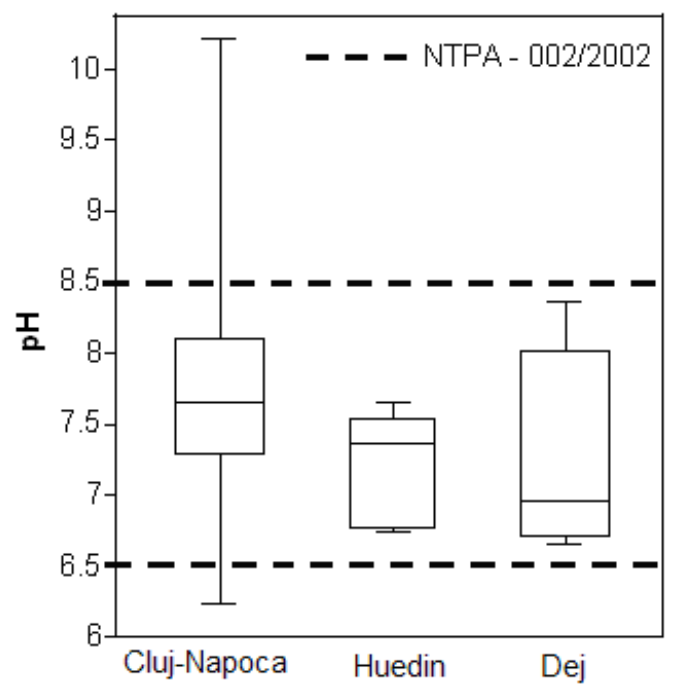

Fig. 2. The $\mathrm{pH}$ values of the analyzed effluents high levels of $\mathrm{BOD}_{5}$ demonstrate the waste waters pollution strength and the oxygen low level disposable for the living organisms.

The results obtained in the present study demonstrate that the values of COD and $\mathrm{BOD}_{5}$ parameters had a significant variation with the effluent origin. The highest values of the COD parameter were obtained in the case of the effluents collected from the Huedin hospital (up to $1875 \mathrm{mg} \mathrm{O}_{2} / \mathrm{l}$ ) and by the dialysis (C_6) and oncologic (C_1) hospitals from Cluj-Napoca, where this parameter reached $991.8 \mathrm{mg} \mathrm{O}_{2} / \mathrm{l}$ and 862.5 mg $\mathrm{O}_{2} / \mathrm{l}$, respectively.

In four (C_1, C_2, C_6 and $\mathrm{H}$ ) of the investigated hospitals the COD concentration exceeded considerably the permissible limits (NTPA $002 / 2002$ ) for waste water discharge in urban sewerage system, showing that these effluents are heavily loaded with organic material (Fig. 4). The data of the present study indicated a seasonal variation for the COD level. As it is shown in Fig. $4 \mathrm{~A}$, the COD concentrations were higher during spring and autumn than in winter and summer. These fluctuations are correlated with the volume and composition of the waste water, the types and quantities of particular drugs which were administrated in the hospitals at those times.

The $\mathrm{BOD}_{5}$ level was lower than the COD and it had a relatively similar variation. The highest $\mathrm{BOD}_{5}$ level (up to $244.2 \mathrm{mg} \mathrm{O}_{2} / \mathrm{l}$ ) was registered

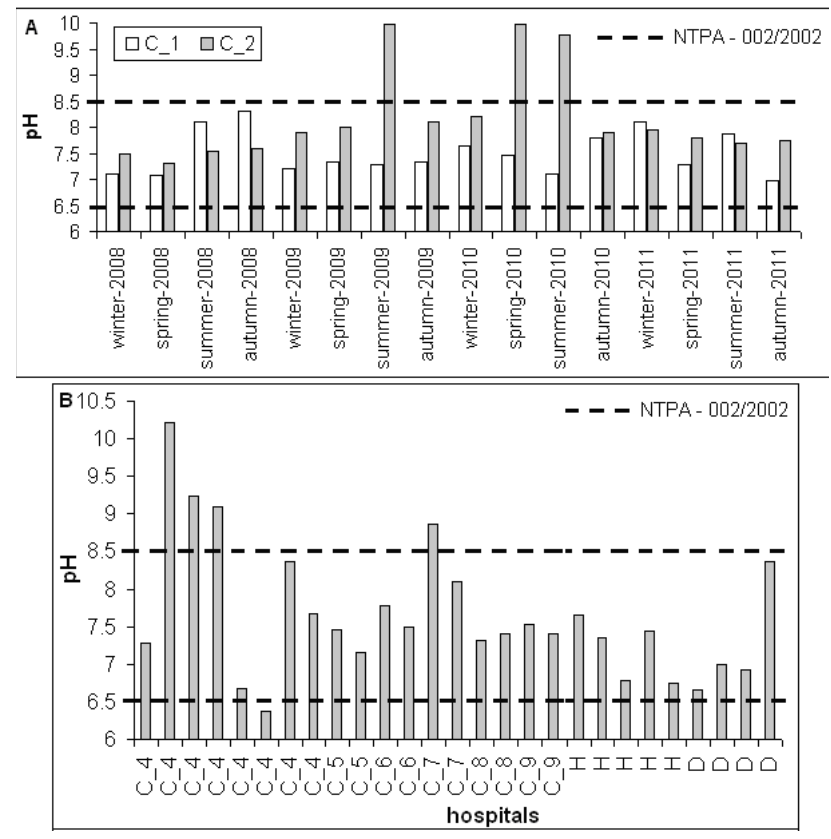

Fig. 3. The pH values of the studied effluents 
in one of the paediatric clinic (C_3) waste water from Cluj-Napoca, while the other effluents had a lower $\mathrm{BOD}_{5}$ level (under $105.6 \mathrm{mg} \mathrm{O}_{2} / \mathrm{l}$ ) (Fig. 5). For all the analyzed samples, the $\mathrm{BOD}_{5}$ level did not exceed the permissible limits $\left(300 \mathrm{mg} \mathrm{O}_{2} / \mathrm{l}\right)$ set by the Romanian legislation (NTPA 002-2002) for effluents discharge into the sewerage network.

The high COD concentrations registered in the up mentioned effluents are a consequence of the use of large amounts of drugs. These effluents have a high oxygen demand which causes dissolved oxygen (DO) depletion. The DO is the most important water quality parameter (Peirce et al., 1997) and it is a fundamental requirement for the aquatic life, especially for the aerobic organisms. The high COD levels can affect the aerobic organisms growth, which can lead to the excessive growth of the anaerobic organisms
(Al-Momani et al., 2002), produce an unaesthetic water colour, and decrease recreational value of water bodies. In the literature, there are many studies where even higher $\mathrm{COD}$ and $\mathrm{BOD}_{5}$ levels are reported. As such, in the effluents generated by a central hospital located in a big city from the southeast of France, the COD level reached 2664 mg $\mathrm{O}_{2} / \mathrm{l}$, while the $\mathrm{BOD}_{5}$ value was up to $1559 \mathrm{mg}$ $\mathrm{O}_{2} / \mathrm{l}$ (Emmanuel et al., 2005).

The COD and BOD5 values indicate the biodegradability of the hospital effluents. Many studies (Al-Momani et al., 2002; Koch et al., 2002) use the $\mathrm{BOD}_{5} / \mathrm{COD}$ ratio as biodegradability index. The waste water can be considered readily biodegradable if it has a $\mathrm{BOD}_{5} / \mathrm{COD}$ ratio between 0.4 and 0.8 (Al-Momani et al., 2002). Values lower than 0.4 suggest that the waste water is difficult

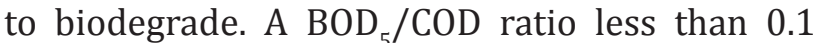
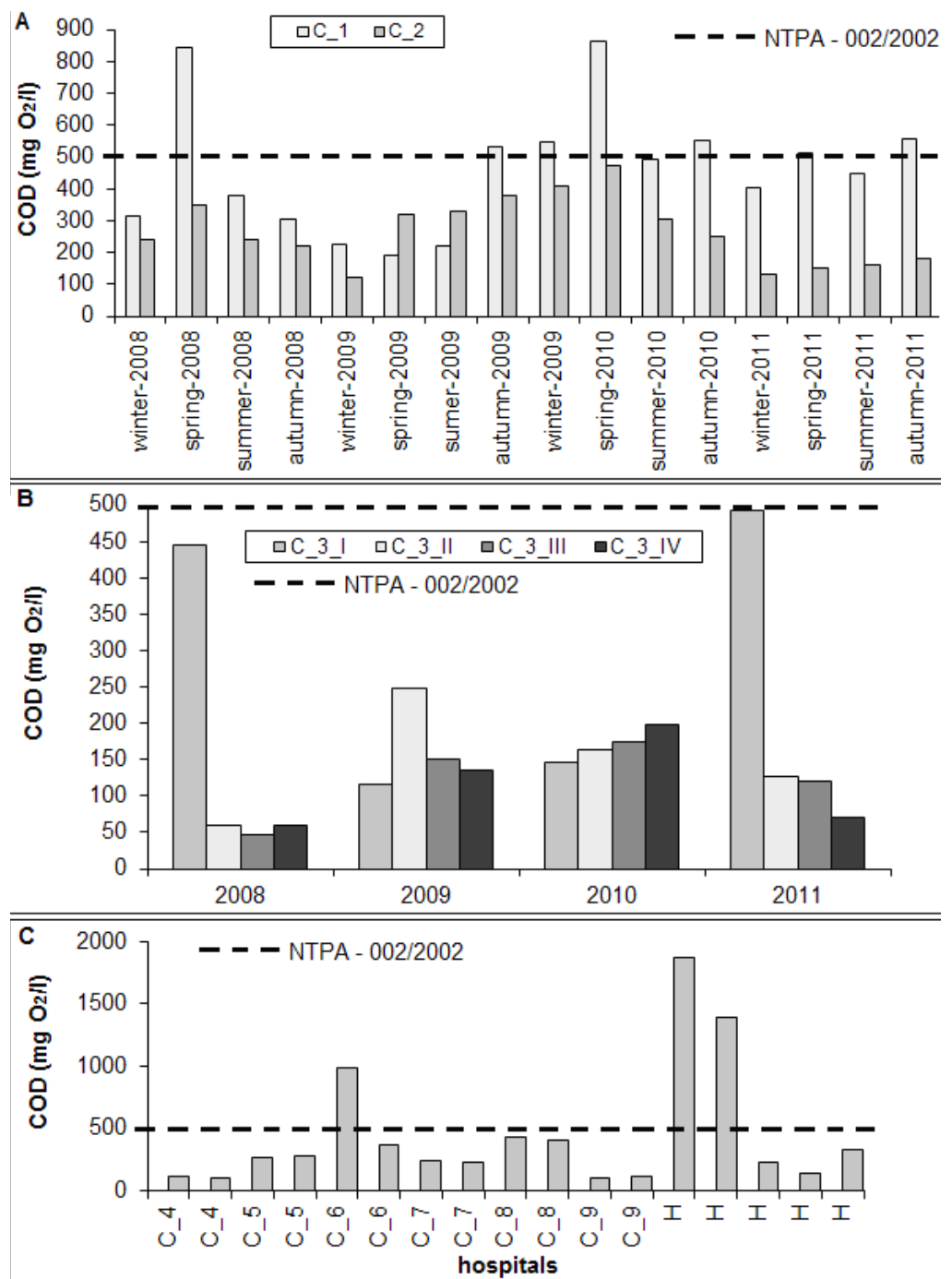

Fig. 4. Details of COD fluctuation in the investigated effluents 
indicate the presence of substances resistant to conventional biological treatment (Koch et al., 2002).

The $\mathrm{BOD}_{5} / \mathrm{COD}$ ratio of the analyzed effluents ranged between 0.18 and 0.99 (Fig. 6).

Most of the effluents collected from different departments of the paediatric clinic (C_3) and the $\mathrm{C}_{-} 2$ had the $\mathrm{BOD}_{5} / \mathrm{COD}$ ration ranged between $0.4-0.8$, values which indicates the presence of the biodegradable substances. Conversely, the other analyzed effluents had a lower $\mathrm{BOD}_{5} / \mathrm{COD}$ ratio (under 0.4 ) demonstrating that these waste waters can be very hard biodegraded using the conventional biological treatment. The low $\mathrm{BOD}_{5} /$ COD ratio indicate the presence some substances that are persistent such as antibiotics, hormones, cytostatics, carbamazepine, X-ray contrast media, carbamazepine and other acidic drugs such as clofibric acid which are very hard biodegradable (Emmanuel et al., 2005).
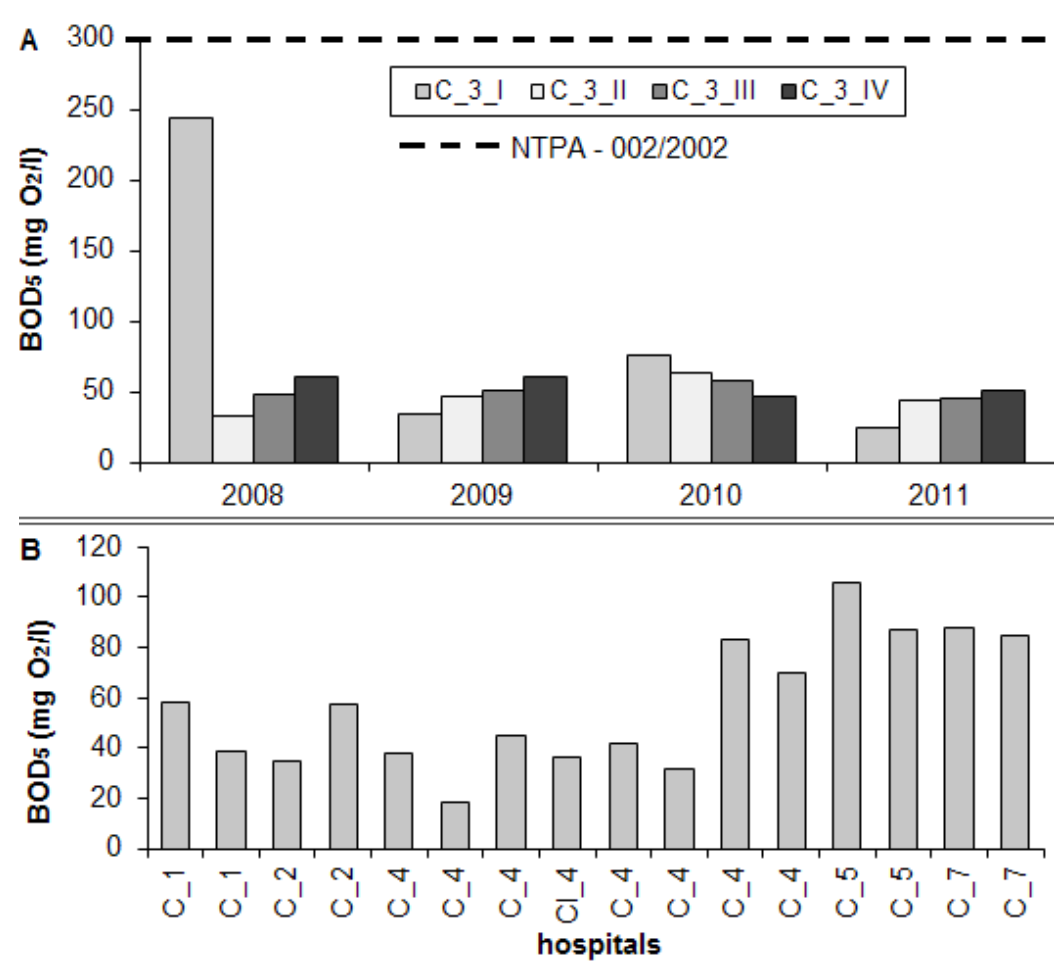

Fig. 5. Details of $\mathrm{BOD}_{5}$ fluctuation in the investigated effluents

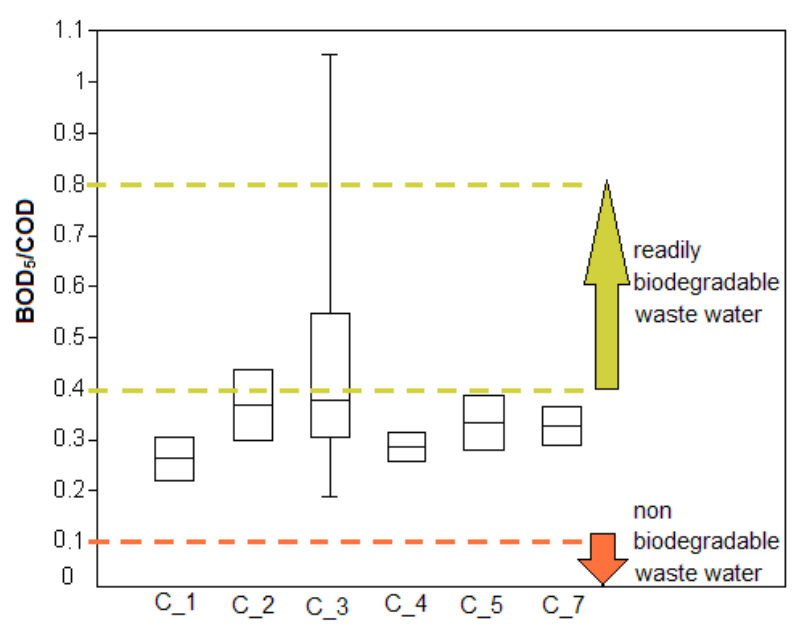

Fig. 6. The $\mathrm{BOD}_{5} / \mathrm{COD}$ ratio of the analyzed effluents 
Total suspended solids (TSS)

Total suspended solids is another important parameter used to characterize the waste water (TSS). The TSS content of the studied effluents was between 18 - $581 \mathrm{mg} / \mathrm{l}$. In the case of the oncologic hospital (C_1) the TSS values were up to $581 \mathrm{mg} / \mathrm{l}$ (Fig. 7). For TSS were registered values up to 329.4 $\mathrm{mg} / \mathrm{l}$ for the C_4 clinic hospital from Cluj-Napoca and up to $362 \mathrm{mg} / \mathrm{l}$ for the central hospital from Dej. The lower values of the TSS were obtained in the case of effluents collected from clinic hospital (C_7), and the gynaecologic (C_8) and urologic (C_9) hospitals from Cluj- Napoca (under $30 \mathrm{mg} / \mathrm{l}$ ). An important situation is the decreasing trend of TSS value obtained for oncologic (C_1) hospital, which had in 2011 an annual average value of $84.25 \mathrm{mg} / \mathrm{l}$ in comparison with $223.1 \mathrm{mg} / \mathrm{l}$ which was the average value in 2008 (Fig. 7 A).

The data indicated a seasonal fluctuation for TSS parameter. In general, the TSS values were higher in the winter and spring than in the summer
(Fig. 7 A). In the literature data are presented studies with similar TSS values for the hospitals effluents (Emmanuel et al., 2005; Abd El-Gawad and Aly, 2011).

The permissible limit for the TSS parameter is $350 \mathrm{mg} / \mathrm{l}$ for effluent discharge in urban sewerage system was exceeded by the effluents collected the oncologic (C_1) hospital from Cluj-Napoca and the one from Dej. Elevated TSS levels can increase the water hardness which will lead to scale formation in pipe-lines and other equipment but they can also be a threat for the aquatic life. A high amount of suspended solids can reduce the light penetration into the water, suppressing photosynthetic activity of phytoplankton, algae, and macrophytes and it can reduce the DO level of waste water (Delée et al., 1998).

\section{Detergents}

Both phosphate and surfactant detergents are often detected in the hospital effluents. The
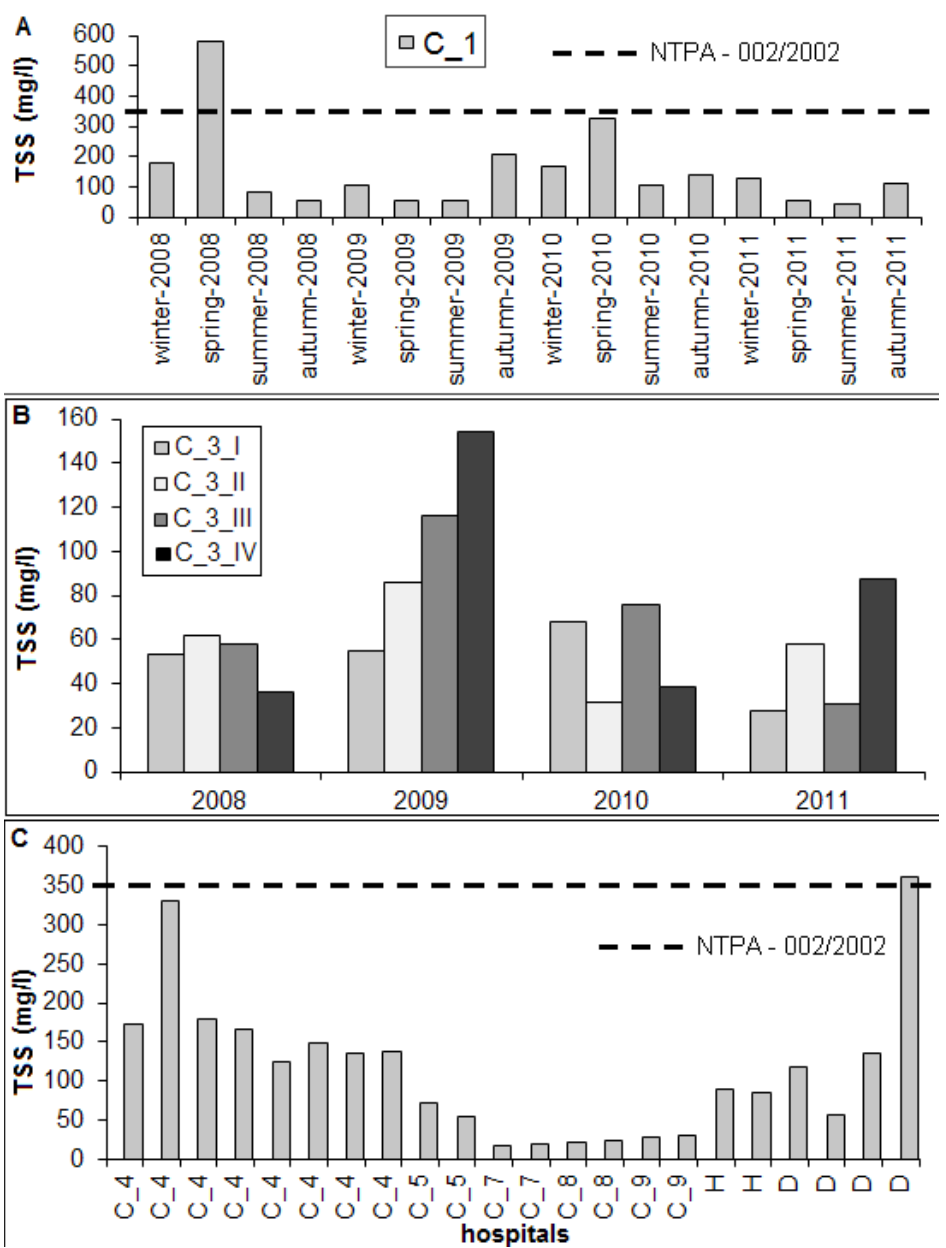

Fig. 7. The variation of TSS values obtained for the studied effluents 


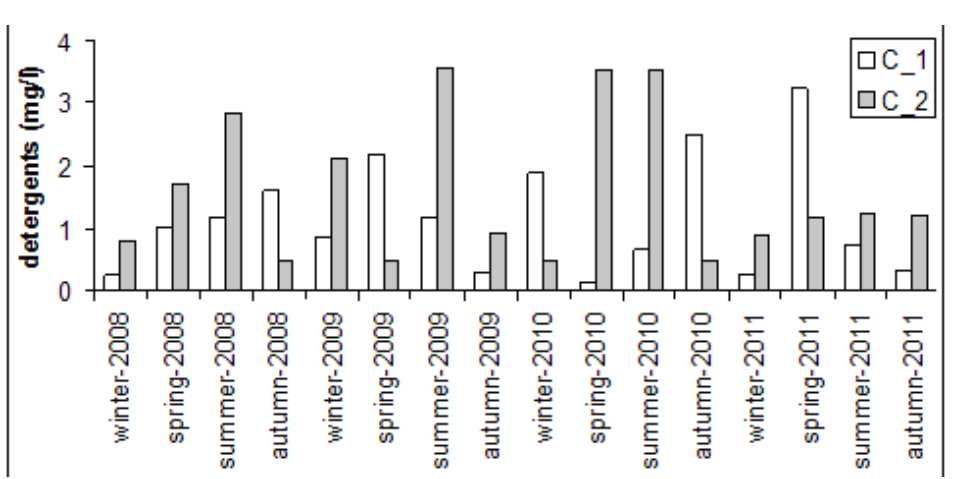

Fig. 8. Detergents content of the analyzed effluents

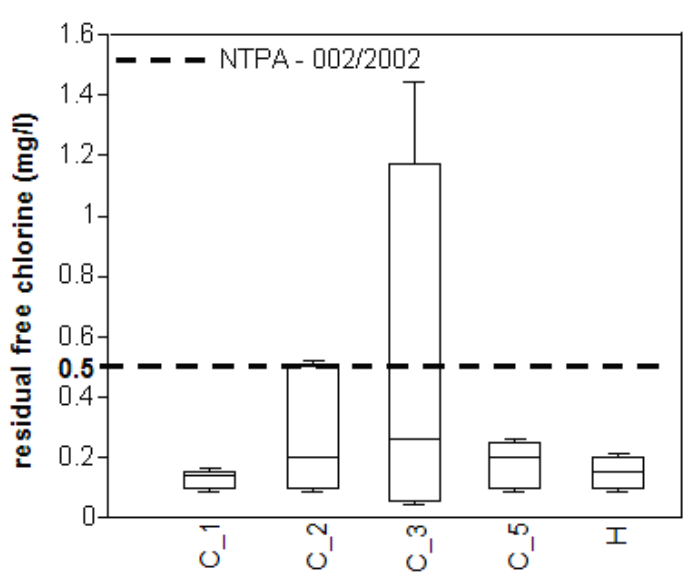

Fig. 9. Residual free chlorine content of the analyzed effluents detergents that contain phosphates are highly caustic, while the surfactant detergents are very toxic (Adewoye, 2010). The presence of detergents in water will decrease the surface tension of the water, which will increase the absorption of organic chemicals such as pesticides and phenols by the fish. For example, the detergent concentration of 2 $\mathrm{mg} / \mathrm{l}$ can double the amount of chemicals normally absorbed by the fish (Adewoye, 2010). At higher concentrations, the impact on the aquatic life is more adverse, for example concentrations up to $5 \mathrm{mg} / \mathrm{l}$ will kill the fish eggs, while at levels of 15 $\mathrm{mg} / \mathrm{l}$, most fish die (Adewoye, 2010).

In the present study the detergents concentrations ranged between $0.15-3.55 \mathrm{mg} / \mathrm{l}$, being higher in the $C_{-} 2$ clinic (between 0.5 $3.55 \mathrm{mg} / \mathrm{l}$ ) than in the oncologic hospital (C_1) (between $0.15-0.23 \mathrm{mg} / \mathrm{l}$ ) (Fig. 8). The detergent content of the analyzed effluents had a significant annual fluctuation, especially during 2009 and 2010. The data indicated a seasonal variation, with higher values during the spring and summer time than in winter and autumn.

In all the analyzed samples the detergent level was lower than the permissible limit of $25 \mathrm{mg} / \mathrm{l}$ for effluent discharge into urban sewerage system (NTPA 002/20002).

\section{Residual free chlorine}

Hospitals use a variety of disinfectants based on chlorine. In order to ensure that water is sufficiently treated through the whole distribution system, an excess of chlorine is usually added before the effluent discharge into the urban sewerage system. However, it is important to maintain a careful balance. An excess of chlorine is not necessary and it may lead to adverse health effects.

In the analyzed effluents the residual free chlorine ranged between $0.04-1.44 \mathrm{mg} / \mathrm{l}$. The lower levels (under $0.25 \mathrm{mg} / \mathrm{l}$ ) were registered in the oncology (C_1) and pneumology (C_5) hospitals from Cluj-Napoca and in the one from Huedin (Fig. 9). The paediatric clinics (C_3) had considerably higher residual chlorine, up to 1.44 $\mathrm{mg} / \mathrm{l}$.

The high level registered in the paediatric clinic is almost triple than the permissible limit $(0.5 \mathrm{mg} / \mathrm{l})$ for waste water discharge in sewerage system. One of the causes for this high chlorine level is the important quantity of chlorine disinfectant used in this clinic. Because of the high amount of chlorine and COD, the discharge of these effluents into the urban sewerage system can have adverse impact on aquatic life and human health. For example the chlorine can react with the organic material in order to form trihalomethanes which proved to be potentially carcinogenic to humans.

\section{CONCLUSIONS}

(1) The analyzed parameters varied significantly with the effluent source.

(2) The parameters annual and seasonal variation was dictated by the types/quantities of drugs administrated in hospitals at those times. Generally the values were higher during the hot season.

(3) The $p H, C O D, T S S$ and residual free chlorine content of some effluents exceeded the permissible limit for sewerage discharge. 
(4) The effluents discharge may have immediate or long-term harmful effect on the aquatic ecosystem and human health. They can produce unaesthetic colour and decrease water recreational value.

(5) Some of the effluents must be treated properly using advanced treatment methods.

\section{REFERENCES}

1. Abd El-Gawad HA, Aly AM (2011). Assessment of Aquatic Environmental for wastewater management quality in the hospitals: a case study. Aust J Basic App Sci 5:474-482.

2. Adewoye SO (2010). Effects of detergent effluent discharges on the aspect of water quality of ASA River, Ilorin, Nigeria. Agric Biol J N Am 1:731-736.

3. Al-Momani F, Touraud E, Dumas JR, Roussy J, Thomas OJ, (2002). Biodegradability enhancement of textile dyes and textile wastewater by UV photolysis. J Photochem Photobiol A 153:191-197.

4. Delée W, Niel CO, Hawkes FR, Pinheiro HM (1998). Anaerobic treatment of textile effluents: a review. J Chem Technol Biot 73:323-335.

5. Emmanuel E, Keck G, Blanchard JM, Vermande P, Perrodin $Y$ (2004). Toxicological effects of disinfections using sodium hypochlorite on aquatic organisms and its contribution to AOX formation in hospital wastewater. Environ Int 30:91-900.

6. Emmanuel E, Perrodin Y, Keck G, Blanchard JM, Vermande $P$ (2005). Ecotoxicological risk assessment of hospital wastewater: a proposed framework for raw effluents discharging into urban sewer network. J Hazard Mater 117:1-11.

7. Heberer $T$ (2002). Occurrence, fate, and removal of pharmaceutical residues in the aquatic environment: a review of recent research data. Toxicol Lett 131:5-17.
8. Koch M, Yediler A, Lienert D, Insel G, Kettrup A, (2002). Ozonation of hydrolysed azo dye reactive yellow 84(CI). Chemosphere 46:109-113.

9. Kümmerer K, (2009). Antibiotics in the aquatic environment - A review - Part II, Chemosphere 75:435441.

10. Kumar A, Bisht BS, Joshi VD, Singh AK, Talwar A (2010). Physical, chemical and bacteriological study of water from rivers of Uttarakhand. J Hum Ecol 32:169-173.

11. Peirce JJ, Weiner RF, Vesilind PA (1997). Environmental Pollution and Control, $4^{\text {th }}$ Edition, ButterworthHeinemann, Woburn, MA, USA, p. 57-74.

12. Sim WJ, Lee JW, Lee ES, Shin SK, Hwang SR, Oh JE (2011). Occurrence and distribution of pharmaceuticals in wastewater from households, livestock farms, hospitals and pharmaceutical manufactures. Chemosphere 82:179186.

13. SR EN 7393/2:2002. Water quality. Determination of free chlorine and total chlorine. Part 2: Colorimetric method using $\mathrm{N}, \mathrm{N}$-diethylphenylen-1,4-diamine, for controlling the routine.

14. SR EN 872:2009. Water quality. Determination of suspended solids content. Method by filtration through glass fiber filters.

15. SR EN 903:2003. Water quality. Determination of anionic surfactants by measurement of the methylene blue index MBAS.

16. SR ISO 10523:2009. Water quality. Determination of $\mathrm{pH}$.

17. SR ISO 1899/1:2008. Water quality. Determination of biochemical oxygen demand after $\mathrm{n}$ days (BODn). Part 1: Dilution and seeding method with the contribution of allylthiourea.

18. SR ISO 6060:1996. Water quality. Determination of chemical oxygen demand.

19. WHO, (1996), Fact sheets on environmental sanitation. Epidemic diarrhoeal diseases control. Geneva, World Health Organization. WHO/EOS/96.4. Eng., 4:43-50. 